\title{
To Determine the Effects of Copper, Zinc and Magnesium in Patients with Pre-Eclampsia
}

\author{
Bushra Jamal, Farheen Shaikh, Muhammad Yousuf Memon
}

\begin{abstract}
OBJECTIVES: Pre-eclampsia is hypertensive and multi-system related disorder of pregnancy. It has frequently labeled as "disease of theories". 5- 10\% of pregnancies complicated due to pre-eclampsia and it is most common health problem worldwide. This study intended to estimates the copper, zinc and magnesium levels in patients with pre-eclampsia.

METHOD: Total eighty subjects were included in the present study, from which $\mathbf{4 0}$ voluntaries were normotensive healthy pregnant women (controls), $\mathbf{4 0}$ were pre-eclamptic patients (cases). The subjects were recruited having symptoms of interest after taking obstetric history, anthropometric and clinical data. After taking informed consent, blood sample collected and stored for biochemical analysis. The serum zinc, copper and magnesium levels were analyzed by Atomic Absorption Spectrophotometer. The study was conducted in biochemistry department during period of eight months from October 2015 to June 2016.

RESULTS: Total eighty subjects were included in present study. The trace elements decreased and shows significant difference between control healthy pregnant and pre-eclamptic women $(p<0.05)$. The mean difference of copper $(0.15 \pm 0.07)$, zinc $(2.94 \pm 0.45)$ and $\mathrm{Mg}^{++}(0.15 \pm 0.09) \mathrm{mg} / \mathrm{dl}$ for the cases group and for control group copper was $(0.20 \pm 0.03)$, zinc $(5.11 \pm 0.21)$ and $\mathrm{Mg}^{++}(2.17 \pm 0.21) \mathrm{mg} / \mathrm{dl}$ respectively. CONCLUSION: Trace elements are essential for the healthy pregnancy, suppressed concentration of serum Zinc, Copper and Magnesium may put forward the possible involvement in the pathology of pre-eclampsia. The aim of this study was to protects the mothers as well as her coming newborn from such life threating disease.

KEYWORDS: Copper, Zinc, Magnesium, Pre-eclampsia, SOD and Atomic Absorption Spectrophotometer.

This article may be cited as: Jamal B, Shaikh F, Memon MY. To Determine the Effects of Copper, Zinc and Magnesium in Patients with Pre-Eclampsia. J Liaquat Uni Med Health Sci. 2017;16 (01):53-7. doi: 10.22442/jlumhs.171610506
\end{abstract}

\section{INTRODUCTION}

Pre-eclampsia (PE) also called pregnancy induced hypertension $(\mathrm{PIH})$ or toxemia. Hypertension in pre-eclampsia characterized by systolic blood pressure $>140 \mathrm{mmHg}$ and diastolic blood pressure $>90 \mathrm{mmHg}$, taking two readings at least 6 hours apart or more apart. ${ }^{1,2}$ PE affects various organs and complicated the pregnancy $2-10 \%$ in the Western world. In Pakistan death rate during pregnancy is predictable to be around 500/ 100,000 live births. ${ }^{7,9}$

The cause of PE is still unclear. It is thought to be early placental dysfunction, during normal pregnancy the intra villous blood pressure established within 1012 weeks but in pre-eclampsia the remodeling of spiral arteries are imperfect. Due to all this coagulating factors stimulated and sign / symptoms of PE will appear. $^{6}$

Pregnancy is a rapid and quick phase of cell development. Therefore, during this phase micronutrients are exposed and excessively depleted. Trace elements are essential for catalytically activity of enzymes and hormones. The deficiencies of trace elements may cause pathology of different diseases. ${ }^{16,20}$

Zinc $\left(\mathrm{Zn}^{++}\right)$is a very important trace element which plays a significant role in cell and growth tissues. The potency and reliability of the heart and blood vessels depend on fundamental components of Copper zinc superoxide dismutase (Cu-Zn-SOD) which is necessary for the cell. In pregnancy $Z^{++}$is reduced due to effect of estrogen, so decline the zinc amount may lead to decrease activity of superoxide dismutase in the cell result in heart dysfunction and PE. ${ }^{4}$

In our body a well balance of micronutrient is present and any imbalance condition reduces the activity of enzymes which effects on cellular changes which may lead to cause blood pressure. ${ }^{5}$

Copper $\left(\mathrm{Cu}^{++}\right)$act as cofactor, help to activate the diversity of enzymes. It also plays an important role as an antioxidant and combined with proteins like ceruloplasmin and $\mathrm{Zn}-\mathrm{Cu} \mathrm{SOD}^{8}$. Decline concentration of $\mathrm{Cu}^{++}$may reduce the activity of $\mathrm{Zn}-\mathrm{Cu}$ SOD and prostacyclin in the large vessels which leads to cause lipid peroxidation and forming free radicals. The main 
role of $\mathrm{Cu}^{++}$is to protect the fetus from free radical injury which may involves in the pathology of PE. ${ }^{6}$

Magnesium $\left(\mathrm{Mg}^{++}\right)$is very important antioxidant, because of its protective property. It protects the blood vessels, improving vascular tone and contractility but due to its deficiency Nitric oxide is released from vascular smooth muscle so, the tone of blood vessel altered and the concentration of calcium also declined. ${ }^{9} \mathrm{Mg}^{++}$and renin angiotensin system has an important correlation with the blood pressure. During the pregnancy renin activity has been dramatically greater than before and effects on magnesium concentration results in increased blood pressure.

It is also used as anticonvulsant, because it competitively antagonize glutamate-N-Methyl, D-Aspartate receptor, which is mainly for epilepsy. ${ }^{5}$ Earlier studies on pre-eclampsia showed that noteworthy turn down the concentration of magnesium ${ }^{12}$

Trace elements are essential for the healthy pregnancy, declined concentration of serum $\mathrm{Zn}^{++}$, $\mathrm{Cu}^{++}$and $\mathrm{Mg}^{++}$may put forward the possible involvement in the pathogenesis of PE. ${ }^{17}$

The aim of this study is to protect the mothers as well as their newborn from such life threating disease.

\section{METERIAL AND METHODS}

Study design: Cross sectional and comparative study.

The study was carried out in the Biochemistry department, LUMHS with the cooperation of department of Gynecology and Obstetrics LUMHS, Jamshoro. The voluntaries were recruited after taking obstetric history, anthropometric, and clinical data.

Inclusion criteria: Healthy pregnant ladies age ranges 17- 46 years, pre-eclamptic women

Exclusion criteria: Known diabetic patients, chronic hypertension, known cardiac patients and on medication

Duration: From October 2015 to June 2016.

Sample size: The sample was calculated according to the Epi software in which pre-eclampsia was $5 \%$ so, the sample size stand to be $n=80$. Total 80 voluntaries were included as one divided into two groups. Group A: $n=40$ normal healthy pregnant women and Group B: $n=40$ patient with Pre-eclampsia.

Sample collection: $5 \mathrm{ml}$ of blood was drawn from recruited subjects either normotensive or pre-eclamptic women by sterilized disposable syringe by venipuncture under aseptic conditions. Transfer the blood to the test tubes or vacationers and then centrifuged at $3000 \mathrm{rpm}$. Stored the sample in sterilized eppendorf cups and preserved at $-18{ }^{\circ} \mathrm{C}$ till analysis. Prior to analysis the sample allowed to stands on the room temperature.
Analytical Procedure: Trace elements were analyzed by AAS (Varian Spectra A- 20). Zinc, copper and magnesium were measured in $\mathrm{mg} / \mathrm{dl}$ according to the method described by Dina M. Abo-Elmatty ${ }^{1}$. The deionized water was used for the dilution factor of ten. The technique is to measure the trace elements from sample by aspiration to the flame from beam of light then reaches to the monochromatic and transmitted to detector for measurement of light absorbance of atomic compounds. Each flame has its own definite wave length 213.9, 225.0 and $273.5 \mathrm{~nm}$ for $\mathrm{Zn}^{++}, \mathrm{Cu}^{++}$ and $\mathrm{Mg}^{++}$respectively.

Data was entered on SPSS (Statistical package for Social Sciences) Version 16 and Microsoft excel. Student "t" test for continuous variable were used for comparison between case and control. Results were obtainable as Mean \& Standard deviation. From all participants was taken written consent and explaining them all about study rationale.

\section{RESULTS}

There were total eighty subjects in this study in which 40 were normotensive women and 40 were patient with pre-eclampsia. The mean age of control subjects was $(25.46 \pm 0.85)$ years, even as for patients it was $(25.76 \pm 0.73)$ years the difference was statistically insignificant $(p=0.8)$. The mean difference of Gestational ages of normal healthy pregnant ladies were $(36.8 \pm 0.27)$ weeks while for the pre-eclamptic subjects it was $(35.32 \pm 0.37)$ weeks the difference was also insignificant statistically $(p=0.76)$.

The mean systolic B.P of cases group was $167.8 \pm 2.54 \mathrm{mmHg}$ whereas in control group it was $120.34 \pm 1.16 \mathrm{mmHg}$. The difference was statistically significant $(p<0.01)$. The mean diastolic B.P in controls was noted as $(74.4 \pm 1.75)$ while in cases $(78.66 \pm 0.96) \mathrm{mmHg}$ whereas $(p<0.01)$ which is highly significant. Body mass index (BMI) mean was (25.30 $\pm 0.36) \mathrm{kg} / \mathrm{m}^{2}$ in patients while $(23.5 \pm 0.28) \mathrm{kg} / \mathrm{m}^{2}$ in control and the difference was statistically significant $(p<0.05)$ which are noted in Table I.

The trace elements were significantly declined as summarized in Table II. The mean value of serum $\mathrm{Cu}^{++}$in cases subjects $(0.15 \pm 0.07) \mathrm{mg} / \mathrm{dl}$ however compared with the control group $(0.39 \pm 0.02) \mathrm{mg} / \mathrm{dl}$ which is statistically significant $(p<0.05)$. The mean of serum $\mathrm{Zn}$ was also reduced in cases group $(2.94 \pm 0.45) \mathrm{mg} / \mathrm{dl}$ on the other hand in control group $(5.11 \pm 0.21) \mathrm{mg} / \mathrm{dl}$ while the difference was statistically significant $(p<0.05)$. The serum $\mathrm{Mg}$ difference was significantly significant $(p<0.05)$ while mean value $(0.15 \pm 0.09) \mathrm{mg} / \mathrm{dl}$ in pre-eclamptic subjects while $(2.17 \pm 0.21) \mathrm{mg} / \mathrm{dl}$ for the healthy pregnant women respectively. 
Bushra Jamal, Farheen Shaikh, Muhammad Yousuf Memon

TABLE I: COMPARISON OF AGE, GESTATIONAL AGE, SYSTOLIC AND DIASTOLIC BLOOD PRESSURES BETWEEN CONTROLS AND CASES

\begin{tabular}{|l|c|c|c|}
\hline \multicolumn{1}{|c|}{ Variables } & Controls & Cases & \multirow{2}{*}{ P-value } \\
\cline { 2 - 4 } & Mean \pm S.D & Mean \pm SD & \\
\hline Age (years) & $25.46 \pm 0.85$ & $25.76 \pm 0.73$ & $0.8 \mathrm{NS}$ \\
\hline $\begin{array}{l}\text { Gestational Age } \\
\text { (Weeks) }\end{array}$ & $36.8 \pm 0.27$ & $35.32 \pm 0.37$ & $0.76 \mathrm{NS}$ \\
\hline $\begin{array}{l}\text { Systolic B.P } \\
\text { (mmHg) }\end{array}$ & $120.34 \pm 1.16$ & $167.8 \pm 2.54$ & $<0.01^{* *}$ \\
\hline $\begin{array}{l}\text { Diastolic B.P } \\
\text { (mmHg) }\end{array}$ & $74.4 \pm 1.75$ & $78.66 \pm 0.96$ & $<0.01^{* *}$ \\
\hline $\begin{array}{l}\text { Body Mass Index } \\
\text { (Kg/m }{ }^{2} \text { ) }\end{array}$ & $23.50 \pm 0.28$ & $25.30 \pm 0.36$ & $<0.05^{*}$ \\
\hline $\begin{array}{l}\text { The values are expressed as (mean } \pm \text { standard) deviation } \\
\& \text { units are given parenthesis. }{ }^{*} p<0.05,{ }^{* *} p<0.01 \text { as com- } \\
\text { pared to controls }\end{array}$ \\
\hline
\end{tabular}

GRAPH I: COMPARISON OF MATERNAL AGE, GESTATIONAL AGE, SBP, DBP AND BMI MEAN VALUES OF CONTROLS AND CASES

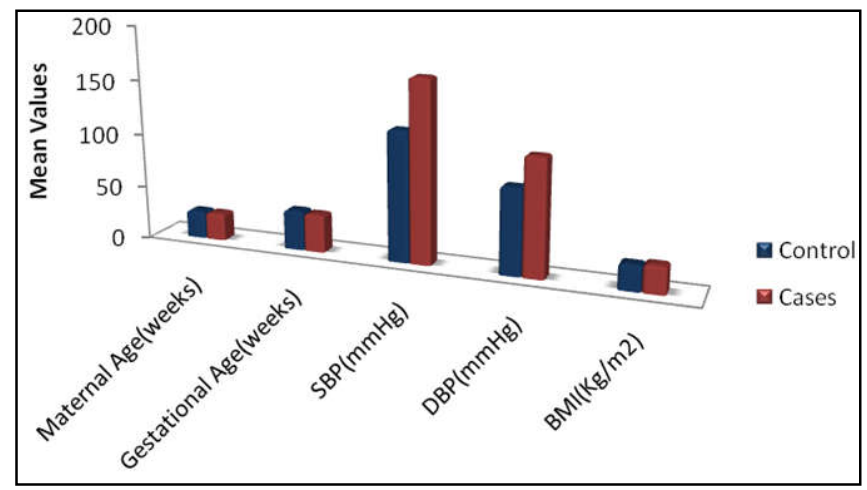

TABLE II: COMPARISON OF ZINC, COPPER AND MAGNESIUM LEVELS BETWEEN CONTROLS AND CASES $(n=80)$

\begin{tabular}{|l|c|c|c|}
\hline \multirow{2}{*}{ Variables } & Controls & Cases & \multirow{2}{*}{ P-value } \\
\cline { 2 - 4 } & Mean \pm S.D & Mean \pm SD & \\
\hline Copper $(\mathrm{mg} / \mathrm{dL})$ & $0.39 \pm 0.02$ & $0.15 \pm 0.07$ & $<0.05^{*}$ \\
\hline Zinc $(\mathrm{mg} / \mathrm{dL})$ & $5.11 \pm 0.21$ & $2.94 \pm 0.45$ & $<0.05^{*}$ \\
\hline $\mathrm{Mg}^{++}(\mathrm{mg} / \mathrm{dL})$ & $2.17 \pm 0.21$ & $0.15 \pm 0.09$ & $<0.05^{*}$ \\
\hline $\begin{array}{l}\text { The values are expressed as (mean } \pm \text { standard) } \\
\text { deviation. Results are presented as } \mathrm{p} \text { values and } \\
\text { calculated by student t-test }{ }^{*} \mathrm{p}<0.05,{ }^{* *} \mathrm{p}<0.01\end{array}$ \\
\hline
\end{tabular}

\section{DISCUSSION}

Pre-eclampsia is one of the foremost causes of
GRAPH II: COMPARISONS OF SERUM ZINC, COPPER AND MAGNESIUM LEVELS BETWEEN CONTROLS AND CASES

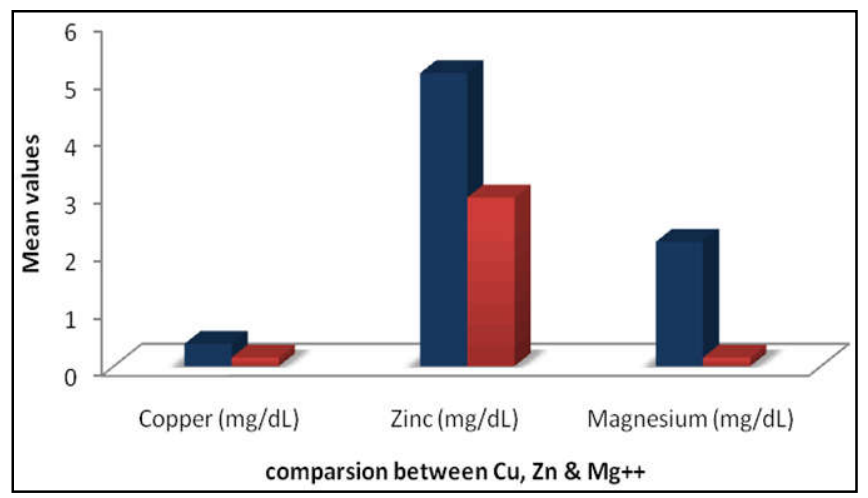

maternal illness which affects on various organs and complicates the pregnancy $2-10 \%$ in the Western world. It is more common in nulliparous about $10 \%$ more than inmultiparous. ${ }^{7}$ It is not only affecting the mother but also on new born. The prevalence of the disease in developed countries has reached immense proportions which represent a major health problem in reproductive age. ${ }^{11,12}$

In present study our results show no significant difference between maternal age of pre-eclamptic women as compared with control groups which supported previous studies $^{5,17}$ however, the gestational age was also insignificant and there is no difference between pre-eclampsia group and control group $(p=0.76)$.

The cause of development of pre-eclampsia is still unclear. According to some studies to sought out the pathophysiology of pre-eclampsia from which research thought that the cause of this life threatening disease is abnormal placenta. ${ }^{13}$ During development of abnormal placenta confrontation of large vessels which releases many angiogenic factors. During this process the epithelium of cytotrophoblast developed pseudo vasculogenesis. Many studies have been shown significant increase in systolic and diastolic blood pressure in pre-eclamptic women than normotensive because of unknown cause. ${ }^{14,15}$ Present study results showing strong evidence of increased blood pressure in pre-eclamptic women as compare with healthy pregnant lady $(p<0.05)$.

The BMI is associated with pregnancy-related complications such as pre-eclampsia or eclampsia many studies revealed that obese women are at high risk for developing hypertension in pregnancy due to increased BMI. ${ }^{18}$ This hypothesis favoring the present study that the BMI was increased significantly in pre-eclamptic patient and prone to develop pregnancy related problems.

Trace elements are essential for the metabolic function of the cell as well as it is very important for the growth and development during pregnancy. The 
serum zinc concentration was decreased significantly and may be a predisposing factor in the development of pre-eclampsia. ${ }^{21}$ The results of present study were shown the declined levels of zinc in pre-eclamptic women as compared with normal healthy women $(p<0.05)$

According to Rafeeinia A. at el $(2014)^{17}$ findings shows increase zinc and copper concentration in patients with pre-eclampsia as compared with controls but our study results shows significant decreased levels of copper and zinc in pre-eclamptic women as compare to healthy ladies. Copper involved in several enzymes like Cu-Zn SOD which is antioxidant defensive enzyme and part of powerful antioxidant ${ }^{12}$ Present study result showed significantly lower levels of copper in pre-eclamptic patients when compared to control subjects $(p<0.05)$. This result is consistent with previously conducted studies. ${ }^{16}$

Many studies reveals the relationship between nutrition and blood pressure in pregnancy since years, it was postulated that there is a direct relationship between the levels of magnesium in the human diet. Magnesium deficiency may increases the plasma cholesterol concentration and lipoproteins thus increasing the risk of pre-eclampsia ${ }^{22}$. Recent research has helped to explain that the decrease concentration of magnesium may be causative factor of pre-eclampsia because the levels are significantly reduced in casa as compared with control. ${ }^{3}$

\section{CONCLUSION}

Trace elements play a very important role during normal pregnancy and development of fetus, as pregnancy precede a head the serum levels of zinc, copper and magnesium reduced therefore, biochemical markers may be associated with the pathogenesis of pre-eclampsia. It would be help in appropriate treatment and protect the mother from life threatening disease.

\section{RECOMMENDATION}

The present study recommended further studies are warranted to be carried out to confirm the present research for recognizing the probable factors related to pre-eclampsia.

\section{ACKNOWLEDGMENT}

Authors would like to thanks to technical advisor of National center of excellence in analytical chemistry, University of Sindh, Jamshoro, who assisted in all stages of study

\section{REFERENCES}

1. Abo-Elmatty DM, Badawy EA, Hussein JS, et al. Role of heme oxygenase, leptin, coenzyme Q10 and trace elements in pre-eclamptic women. Indian J Clin Biochem. 2012;27(4):379-84.

2. Adekanle DA, Adeyemo OT, Adeniyi AA, et al. Serum magnesium levels in healthy pregnant and pre-eclamptic patients- A cross-section study. OJOG. 2014; 4(9)561-8.

3. Cunha AR, Umbelino B, Correia ML, Neves MF. Magnesium and vascular changes in hypertension. Int J Hyperten. 2012; 1:1-7.

4. Lou SG, Amirabi A, Yazdian M, Pashapour N. Evaluation of serum calcium, magnesium, copper, and zinc levels in women with pre-eclampsia. IJMS.2008; 33(4):231-4.

5. Singh A, Kumar A, Hassan G, et al. Serum menesium levels in patient with pre-eclampsia and Eclampsia with different regimens of Megnisium Sulphate. G J MED PH. 2013;2(1):1-9.

6. Omar Elind A-H. Trace elements as potential biomarkers of Preeclampsia. ARRB.2016;9(1):1-10.

7. Aziz R, Mahboob T. Serum calcium, magnesium and parathyroid hormone in normal pregnant and pre-eclamptic women in Karachi, Pakistan. Journal of Hypertension-Open Access. 2014; 3(2):1-3.

8. Brito JA, do Nascimento Marreiro D, Moita Neto $\mathrm{JM}$, et al. Enzyme activity of superoxide dismutase and zincemia in women with preeclampsia. Nutr Hosp. 2013; 28(2):486-90.

9. Ephraim RK, Osakunor DN, Denkyira SW, et al. Serum calcium and magnesium levels in women presenting with pre-eclampsia and pregnancyinduced hypertension: a case-control study in the Cape Coast metropolis, Ghana. BMC Pregnancy Childbirth. 2014;14:390.

10. Farzin L, Sajadi F. Comparison of serum trace element levels in patients with or without preeclampsia. J Res Med Sci. 2012; 17(10):938-41.

11. English FA, Kenny LC, McCarthy FP. Risk factors and effective management of preeclampsia. Integr Blood Press Control. 2015;8:7-12.

12. Garg DK, Mahat RK, Arora M, et al. Study of serum calcium, magnesium and uric acid in pre-eclamptic and normal pregnant women. IJHSR. 2015;5(6):263-8.

13. Gupte S, Wagh G. Preeclampsia-Eclampsia. J Obstet Gynaecol India. 2014;64(1):4-13.

14. Kim J, Kim YJ, Lee R, Moon JH, Jo I. Serum levels of zinc, calcium, and iron are associated with the risk of preeclampsia in pregnant women. Nutr Res. 2012; 32(10):764-9.

15. Krishna TS, Rao EV, Naidu JN. Alterations of antioxidant enzymes in preeclampsia. Int $\mathrm{J}$ Res med Sci. 2015; 3(9):2348-51.

16. Lassi ZS, Mallick D, Bhutta ZA. The role of micronutrients in the prevention of congenital anomalies in the fetus and optimization of pregnancy 
outcomes. Tremellen KP, Pearce K (eds): Nutrition, Fertility and Human Reproductive Function. CRC Press, Taylor and Francis Group. 2015 ISBN 9781482215304 - CAT\# K21796.

17. Rafeeinia A, Tabandeh A, Khajeniazi S, Marjani AJ. Serum copper, zinc and lipid peroxidation in pregnant women with preeclampsia in Gorgan. Open Biochem J. 2014;8:83-7.

18. Shen PJ, Gong B, Xu FY, et al. Four trace elements in pregnant women and their relationships with adverse pregnancy outcomes. European Review for Medical and Pharmacological Sciences. 2015;19(24):4690-7.

19. Ugwuja El, Ejikeme BN, Ugwu NC, et al. Comparison of plasma copper, iron and zinc levels in hypertensive and non-hypertensive pregnant women in Abakaliki, South Eastern Nigeria. Pak. J. Nutr. 2010; 9(12):1136-40.

20. Zhang $X, X u Z$, Lin F, Wang F, Ye D, Huang Y. Increased oxidative DNA damage in placenta contributes to cadmium-induced preeclamptic conditions in rat. Biol Trace Elem Res. 2015;170:119.

21. Zhu Q, Zhang L, Chen X, Zhou J, Liu J, Chen J. Association between zinc level and the risk of preeclampsia: a meta-analysis. Arch Gynecol Obstet.2016;293(2):377-82.

22. Tavana Z, Hosseinmirzaei S. Comparison of maternal serum magnesium level in pre-eclampsia and normal pregnant women. Iran Red Crescent Med J. 2013; 15(12):e10394.

AUTHOR AFFILIATION:
Dr. Bushra Jamal
Department of Biochemistry
Liaquat University of Medical and Health Sciences
(LUMHS), Jamshoro, Sindh-Pakistan.
Dr. Farheen Shaikh (Corresponding Author)
Department of Biochemistry
LUMHS, Jamshoro, Sindh-Pakistan.
Dr. Muhammad Yousuf Memon
Department of Biochemistry
LUMHS, Jamshoro, Sindh-Pakistan.

